\begin{tabular}{|ccc|}
\hline & Uniqbu Journal Of Social Sciences (UJSS) \\
\hline Volume 1 & Nomor 1, April 2020 & Halaman 25-37 \\
\hline
\end{tabular}

\title{
MAKNA DAN FUNGSI EMOSI MAHASISWA KOTA BAUBAU DALAM RANAH DEMONSTRASI \\ (The Meaning and Emotional Function of BauBau City Students in the Demonstration Plan)
}

\author{
Risman Iye ${ }^{a}$ A. Yusdianti Tenriawali b Susiati, Azwan and Darwis Buton

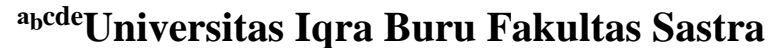

Jl. Prof. Dr. H. A.R. Basalamah No. 20 Telp. (0913) 21909, Namlea-Kab. Buru

Pos-el: rismanive@gmail.com

(Diterima: 07 April; Direvisi 11 April; Disetujui: 20 April 2020)

\begin{abstract}
The lexical meaning and the meaning of the context are not always appropriate, so it is necessary to research to avoid misinterpretation of the content of the speech in the realm of the demonstration. This study aims to explain: the meaning of context and emotional function of Baubau City students in the field of demonstration. This research is a type of qualitative research. Sampling is done purposively. Oral data is collected using the method of free-of-cognate, documentation techniques, and notes. Data were analyzed with Searle's speech acting theory and Goleman's theory. The results showed that the meaning of context and emotional speech function of Baubau City students in the realm of demonstration, namely the use of the context is dominant in contextual meanings rather than lexical meaning so that many words, phrases, sentences, and phrases are semantically positive. However, it is pragmatically negative. The emotional speech function of mahasiswa consists of four, namely assertive, declarative, directive, and expressive.
\end{abstract}

Keywords: meaning, student emotion, demonstration

Abstrak

Makna leksikal dan makna konteks tidak selamanya sesuai sehingga perlu dilakukan penelitian untuk menhindari kesalahan penafsiran terhdadap isi tuturan dalam ranah demonstrasi tersebut. Penelitian ini bertujuan menjelaskan: makna konteks dan fungsi emosi mahasiswa Kota Baubau dalam ranah demonstrasi;.Penelitian ini merupakan jenis penelitian kualitatif. Pengambilan sampel dilakukan secara purposif. Data lisan dikumpullkan menggunakan metode simak bebas cakap, teknik dokumentasi, dan catat. Data dianalisis dengan teori tindak tutur Searledan teori Goleman.Hasil penelitian menunjukan bahwamakna konteks dan fungsi tuturan emosi mahasiswa Kota Baubau dalam ranah demonstrasi, yaitu penggunaan makna konteks tuturannya dominan pada makna kontekstual daripada makna leksikal sehingga banyak kata, frasa, kalimat, serta ungkapan yang secara semantik bermakna positif. Namun, secara pragmatik bermakna negatif. Fungsi tuturan emosi mahsiswa terdiri atas empat, yaitu asertif, deklaratif, direktif, dan ekspresif.

Kata kunci: Makna, emosi mahasiswa, demostrasi

\section{PENDAHULUAN}

Dalam kehidupan sehari-hari, seseorang tidak dipandang sebagai individu terpisah dari yang lainnya. Ia secara langsung merupakan bagian dari masyarakat yang ada di sekitarnya. Masyarakat adalah sekelompok manusia yang telah cukup lama hidup dan bekerja sama sehingga mereka dapat mengorganisasikan dirinya dan berpikir tentang dirinya dalam satu kesatuan sosial (Abdulsyani, 1994). Di dalamnya terdapat interaksi, pola tingkah laku yang khas, dan ikatan rasa identitas masingmasing individu terhadap kelompoknya.

Bahasa memunyai peranan penting dalam kehidupan manusia. Selain sebagai media komunikasi, bahasa juga dapat 
digunakan seseorang untuk mengekspresikan dirinya dan segala hal yang dirasakan untuk diungkapkan kepada orang lain. Melalui bahasa pula, seseorang dapat mengungkapkan emosinya, baik emosi positif maupun emosi negatif. Salah satu hal yang berhubungan dengan pengungkapan emosi negatif, yaitu makian. Kata-kata makian sering ditemukan dalam demontrasi karena mahasiwa cenderung menggunakan bahasa yang kasar dan tidak ditutup-tutupi. Salah satu bentuk pemakaian tuturan emosi ini banyak ditemukan di Kota Baubau.

Sebagai makhluk hidup, manusia tentunya tidak lepas dari emosi, baik emosi positif maupun emosi negatif. Emosi positif adalah ungkapan jiwa seseorang untuk menyatakan perasaan senang atau gembira. Sebaliknya, emosi negatif adalah ungkapan jiwa seseorang untuk menyatakan perasaan sakit hati, marah, kecewa, sedih, terkejut, kesal, dan sebagainya yang dapat diungkapkan melalui bahasa. Dalam menyampaikan maksudnya atau mengungkapkan emosinya itu, manusia menggunakan bahasa yang berbeda-beda. Mereka kadang-kadang menggunakan bahasa yang lebih halus agar tidak menyinggung perasaan orang yang diajak berbicara. Akan tetapi, manusia juga sering menggunakan bahasa yang lebih kasar dari yang sebenarnya. Ia menggunakan bahasa dengan maksud tertentu. Agar maksudnya tercapai, ia harus melihat situasi dan kondisi pada saat dia mulai berbicara.

Pemakaian tuturan emosi tidak
terlepas dari beberapa hal yang memengaruhinya yaitu, latar atau suasana. Keterkaitan penggunaan bahasa dengan konteks (situasi tutur) yang menyertai bahasa tersebut merupakan salah satu hal yang menarik dalam kajian pragmatik. Penggunaan bahasa dalam percakapan sehari-hari sering mengandung makna yang berbeda dalam konteks yang berbeda pula.
Dengan kata lain, arti dari sebuah kata harus disesuaikan dengan konteks kalimatnya.

Seiring perkembangan waktu dalam dunia mahasiswa seringkali kita temukan beragam kebiasaan yang tidak terlepas, yaitu demonstrasi dimana kegiatan ini merupakan aksi menyampaikan aspirasi di tempat umum dengan maksud dan tujuan menyuarakan segala macam kebijakankebijakan yang diambil oleh pemegang otoritas (pemimpin atau penguasa) yang tidak prorakyat. Di setiap negara demokrasi termasuk Indonesia segala bentuk aspirasi rakyat bisa disampaiakan secara bebas dan terbuka. Kebebasan berpendapat, berpikir, berkumpul, dan seterusnya mendapatkan tempatnya.

Melalui demonstrasi, keinginan dan cita-cita masyarakat diharapkan bisa didengar, diperhatikan, dan direspon oleh pihak-pihak yang dituju, terutama pemerintah atau pemimpin. Namun, penyampaian aspirasi tersebut seringkali diwarnai tindakan yang destruktif-anarkistis. Demonstrasi merupakan kegiatan yang sering kita jumpai dalam kehidupan masyarakat yang pada umumnya dilakoni oleh mahasiswa. Terlepas dari semua itu seringkali peserta demonstrasi dalam menyampaikan aspirasinya cenderung menggunakan tuturan emosi dalam isi penyampaianya.

Dalam berdemonstrasi tentu bahasa digunakan sebagai alat komunikasi untuk menyampaikan aspirasi tersebut baik berupa kata, frasa, kalimat maupun ungkapan yang memunyai fungsi tersendiri karena dipengaruhi oleh faktor situasional saat pembicara menuturkan tuturanya.

Tujuan penelitian ini, yaitu menganalisis makna konteks dan fungsi tuturan emosi mahasiswa Kota Baubau dalam ranah demonstrasi.

\section{LANDASAN TEORI}

Landasan teori dijabarkan dari tinjauan pustaka dan disusun oleh penulis sebagai kerangka acuan dalam memecahkan 

masalah. Landasan teori bukan sekadar sekumpulan definisi suatu istilah. Uraian dalam bab ini menggunakan acuan yang relevan, kuat, tajam, dan mutakhir. Teori yang ditulis dalam bab ini adalah teori yang digunakan dalam analisis data atau pembahasan.

\section{Pragmatik}

Levinson (dalam Risman 2018) menyatakan bahwa pragmatik memiliki dua pengertian, pertama kajian dari hubungan antara bahasa dan konteks yang mendasari penjelasan dari pengertian bahasa. Pengertian bahasa menunjukkan kepada fakta bahwa untuk mengerti suatu ungkapan atau ujaran bahasa yang diperwakilkan oleh pengetahuan di luar makna kata dan hubunganya dengan konteks pemakainya. Kedua, kajian tentang kemampuan pemakaian bahasa mengaitkan kalimatkalimat dengan konteks-konteks yang sesuai bagi kalimat-kalimat itu.

Menurut Leech (1993), pragmatik adalah studi tentang makna dalam hubungannya dengan situasi ujar (speech situations). Pragmatik diperlukan dengan menganalisis makna yang dipertuturkan antara penutur disesuaikan dengan situasi ujar.

Hal senada juga di ungkapkan oleh Gusnawaty (2011) pragmatik berfokus utama pada dua kunci, yakni penggunaan bahasa dan konteksnya; dan makna yang ditimbulkan akibat interaksi sosial yang bergantung pada hubungan solidaritas atau jarak antara interlekutor. Cahyono (1995) menyatakan bahwa pragmatik merupakan cabang ilmu bahasa yang mempelajari tentang makna yang dikehendaki oleh penutur, pendapat tersebut lebih menekankan pada makna yang dikehendaki penutur.

\section{Tindak Tutur}

Tindak tutur (speech art) merupakan unsur pragmatik yang melibatkan pembicara, pendengar atau penulis pembaca serta yang dibicarakan. Dalam penerapannya tindak tutur digunakan oleh beberapa disiplin ilmu. Adapun pengertian tindak tutur yang dikemukakan oleh para ahli bahasa, antara lain: Austin, Searle, Chaer, dan Tarigan.

Austin (dalam Rusminto, 2010) pertama kali mengemukakan istilah tindak tutur. Austin mengemukakan bahwa aktivitas bertutur tidak hanya terbatas pada penuturan sesuatu, tetapi juga melakukan sesuatu atas dasar tuturan itu. Pendapat Austin ini didukung oleh Searle (dalam Rusminto, 2010) dengan mengatakan bahwa unit terkecil komunikasi bukanlah kalimat, melainkan tindakan tertentu, seperti membuat pernyataan, pertanyaan, perintah, dan permintaan.

Berdasarkan uraian beberapa tokoh di atas dapat disimpulkan bahwa tindak tutur adalah suatu ujaran yang mengandung tindakan sebagai suatu fungsional dalam komunikasi yang mempertimbangkan aspek situasi tutur.

\section{Situasi Tutur}

Situasi tutur adalah situasi yang melahirkan tuturan. Pernyataan ini sejalan dengan pandangan bahwa tuturan merupakan akibat, sedangkan situasi tutur merupakan sebabnya. Di dalam komunikasi tidak ada tuturan tanpa situasi tutur. Situasi tutur sangat penting di dalam pragmatik.

Maksud tuturan yang sebenarnya hanya dapat diidentifikasi melalui situasi tutur yang mendukungnya. Rustono (1999) menyatakan bahwa tidak selamanya tuturan itu secara langsung menggambarkan makna yang dikandung oleh unsur-unsurnya.

Rahardi (2002) membagi aspek-aspek situasi tutur menjadi lima macam, yaitu:

1) Penutur dan lawan tutur

Penutur dan lawan tutur di dalam beberapa literatur, khususnya dalam Searle (dalam Rustono, 1999) lazim dilambangkan dengan $S$ (speaker) yang berarti pembicara atau penutur, dan $\mathrm{H}$ (hearer) yang dapat diartikan pendengar atau mitra tutur. Lambang $\mathrm{S}$ dan $\mathrm{H}$ itu tidak semata-mata 
hanya dengan sendirinya membatasi cakupan pragmatik hanya pada bahasa ragam lisan saja, melainkan dapat mencakup ragam bahasa tulis.

2) Konteks tuturan

Konteks tuturan telah diartikan bermacam-macam pleh para linguis. Konteks dapat mencakup aspek-aspek tuturan yang relevan baik secara fisik maupun nonfisik. Konteks dapat pula diartikan sebagai semua latar belakang pengetahuan yang diasumsikan sama-sama dimiliki penutur dan mitra tutur serta yang mendukung interprestasi mitra tutur atas apa yang dimaksudkan penutur dalam proses bertutur.

3) Tujuan tuturan

Tujuan tuturan berkaitan erat dengan bentuk tuturan seseorang. Dikatakan demikian karena pada dasarnya tuturan itu terwujud karena dilatarbelakangi oleh maksud dan tujuan tutur yang jelas dan tertentu sifatnya. Secara pragmatik, suatu bentuk tutur dapat memiliki maksud dan tujuan tutur dapat diwujudkan dengan bentuk tuturan yang berbeda-beda.

4) Tuturan sebagai tindakan

Tuturan sebagai bentuk tindakan atau aktivitas merupakan bidang yang ditangani pragmatik karena pragmatik mempelajari tindak yang terdapat dalam situasi tutur tertentu. Dapat dikatakan bahwa yang dibicarakan dalam pragmatik bersifat kongkret karena jelas keberadaan siapa peserta tuturanya, di mana tempat tuturanya, kapan waktu tuturanya, dan seperti apa konteks situasi tuturnya secara keseluruhan.

5) Tuturan sebagai produk tindak verbal

Tuturan dapat dipandang sebagai

produk tindak verbal karena pada dasarnya tuturan yang ada dalam sebuah pertuturan itu adalah hasil tindak verbal para peserta tutur dengan segala pertimbangan konteks yang melingkupi dan mewadahinya.

\section{Komponen Tutur}

Pemakaian bahasa dalam komunikasi, selain ditentukan oleh faktor-faktor linguistik juga ditentukan oleh faktorfaktor yang bersifat nonlinguistic. Pandangan tersebut beralasan karena pada dasarnya bahasa adalah bagian yang tidak terpisahkan dari sistem sosial. Menurut Poedjosoedarmo (dalam Rahardi, 2002) faktor luar bahasa (extra linguistic) yang dikatakan sebagai penentu penggunaan bahasa dalam bertutur dapat disebut sebagai komponen tutur (component of speech). Setiap tuturan atau ujaran manusia dalam berkomunikasi selalu berkaitan erat dengan komponen tutur. Namun, tidak semua komponen tutur muncul sekaligus dalam sebuah tuturan. Hal ini disebabkan setiap komponen tutur tersebut memiliki peran dan fungsi yang berbeda dalam membentuk sebuah tuturan.

Sejalan dengan masalah yang diteliti, dipakai dasar penelitian yang menyatakan bahwa wujud ujaran (speech) atau tuturan (utterance)itu ditentukan dan dipengaruhi oleh beberapa faktor. Hymes (dalam Chaer dan Agustina, 2004) membuat formulasi tentang faktor-faktor penentu sebuah tuturan yang apabila huruf-huruf pertamanya dirangkaikan menjadi akronim SPEAKING. Kedelapan faktor tersebut yaitu:

1) Setting berkenaan dengan waktu dan tempat tutur berlangsung, sedangkan scene mengacu pada situasi tempat dan waktu, atau situasi psikologis pembicaraan.

2) Participants adalah pihak-pihak yang terlibat dalam tuturan. Misalnya, pembicara dan pendengar, penyapa dan pesapa, atau pengirim dan penerima (pesan). Status sosial partisipan sangat menentukan ragam bahasa yang digunakan petutur.

3) Ends merujuk pada maksud dan tujuan pertuturan. Peristiwa tutur yang terjadi di ruang pengadilan bermaksud untuk menyelesaikan suatu kasus perkara; namun, para partisipan di dalam peristiwa tutur itu memunyai tujuan yang berbeda. Jaksa ingin membuktikan kesalahan si terdakwa, pembela berusaha membuktikan bahwa si terdakwa tidak bersalah, sedangkan hakim berusaha memberikan keputusan yang adil. 
4) Act sequences mengacu pada bentuk ujaran dan isi ujaran. Bentuk ujaran ini berkenaan dengan kata-kata yang digunakan, bagaimana penggunaannya, dan hubungan antara apa yang dikatakan dengan topik pembicaraan.

5) Key mengacu pada nada, cara, dan semangat dimana suatu pesan disampaikan: dengan senang hati, dengan serius, dengan singkat, dengan sombong, dengan mengejek, dan lain-lain. Hal ini dapat juga ditunjukkan dengan gerak tubuh dan isyarat.

6) Instrumentalities mengacu pada jalur bahasa yang digunakan seperti jalur lisan, tertulis, melalui telegraf atau telepon. Instrumentalities ini juga mengacu pada kode ujaran yang digunakan, seperti bahasa dialek, ragam, atau register.

7) Norm of interaction and interpretation mengacu pada norma atau aturan dalam berinteraksi. Selain itu, juga mengacu pada norma penafsiran terhadap ujaran dari lawan bicara.

8) Genre mengacu pada jenis bentuk penyampaian, seperti narasi, puisi, pepatah, doa, dan lain-lain.

\section{Emosi}

Emosi berasal dari kata emotus atau emovere yang artinya 'mencerca' (to stir up), yaitu sesuatu yang mendorong terhadap sesuatu. (Dirgagunarsa, 1978). Misalnya, emosi gembira mendorong perubahan suasana hati seseorang yang menyebabkan orang itu tertawa. Marah, dilain pihak, merupakan suasana hati untuk untuk menyerang atau mencerca sesuatu. Emosi pada umumnya disifatkan sebagai keadaan (state) yang ada pada individu atau organisme pada sesuatu waktu. Misalnya, seseorang merasa sedih, senang, takut, marah ataupun gejala-gejala yang lain setelah melihat, mendengar atau merasakan sesuatu.

Menurut Walgito (2003) emosi merupakan reaksi yang kompleks yang mengandung aktivitas dengan derajat yang tinggi dan adanya perubahan dalam kejasmanian serta berkaitan dengan perasaan yang kuat. Oleh karena itu, emosi lebih intens dari pada perasaan, dan sering terjadi perubahan perilaku, hubungan dengan lingkungan kadang-kadang terganggu.

Nurhayati (2006), mengatakan bahwa perasaan menyangkut keadaan kejiwaan dan keadaan jasmani. Selanjutnya, perasaan ini jika terlalu berlebihan, maka untuk mengadakan hubungan dengan sekitarnya terganggu, hal ini akan memasuki wilayah emosi.

Goleman (2001:411), emosi adalah setiap kegiatan atau pergolakan perasaan, pikiran, nafsu, setiap keadaan mental yang hebat dan meluap-luap dan emosi merujuk kepada suatu perasaan dan pikiran- pikiran yang khas, suatu keadaan biologis dan psikologis dari serangkaian kecenderungan untuk bertindak. Goleman juga mengatakan bahwa emosi dasar negatif adalah perasaan individu yang dirasakan kurang menyenangkan (ketakutan, kekhawatiran, kecemasan, kebencian, kemarahan) yang berlebihan yang dapat membuat individu bertindak dengan sangat tidak rasional atau di luar kontrol.

Dari beberapa pengertian tokoh di atas, maka maka dapat didefinisikan bahwa tuturan emosi adalah bentuk bahasa yang merupakan hasil dari pengungkapan, pengeluaran, atau pengucapan segala macam perasaan dari jiwa seseorang. Pengertian tuturan di sini sama sekali tidak dihubungkan dengan pengertian tuturan yang bermakna semacam peribahasa.

\section{Makna Konteks Tuturan}

Makna memegang peranan tergantung dalam pemakaian bahasa sebagai alat untuk penyampaian pengalaman jiwa, pikiran, dan maksud dalam masyarakat. Ullman (1972), apabila seseorang memikirkan maksud sesuatu perkataan, sekaligus memikirkan rujukannya atau sebaliknya. Makna adalah arti atau maksud dari sebuah tuturan dan tindakan. 

Dalam percakapan sehari-hari seringkali mendengar tuturan atau tindakan yang mengandung sebuah makna atau maksud tertentu. Tuturan dan tindakan tersebut terkadang mengandung makna atau maksud yang berbeda dalam konteks yang berbeda pula. Dengan kata lain, maksud dari sebuah kata harus disesuaikan dengan konteks kalimatnya. Beberapa kata dalam setiap tuturan yang diketahui secara umum berdasarkan pengertiannya dan ada pula kata yang maknanya timbul dan berkembang karena situasi pembicaraan. Hubungan dua hal antara maksud dengan perkataan itulah lahir makna, oleh yang demikian walaupun rujukan tetap, akan tetapi makna dan perkataan dapat berbeda.

Bahasa digunakan untuk berbagai kegiatan dan keperluan dalam kehidupan bermasyarakat, makna bahasa itu pun menjadi bermacam- macam dilihat dari segi atau pandangan yang berbeda. Chaer (2012) membagi jenis-jenis makna sebagai berikut, "Makna leksikal, gramatikal, kontekstual, referensial dan non referensial, denotatif, konotatif, konseptual, asiosiatif, kata, istilah, idiom serta makna peribahasa.

Makna kontekstual adalah makna sebuah kata atau gabungan kata atau suatu ujaran di dalam konteks pemakaiannya. Makna ini muncul sebagai akibat antara ujaran dan konteks. Banyak faktor yang memengaruhi konteks ini, yaitu : konteks pembicara, kebahasaan, waktu, tujuan, situasi atau suasana hati si pembicara/pendengar, objek pembicaraan, dan lain-lain.

Sesuai dengan objek yang diteliti, yaitu tuturan emosi bahasa Indonesia, maka pemaknaan dari tiap tuturan emosi mahasiswa Kota Baubau dalam ranah demonstrasi menggunakan makna kontekstual. Makna kontekstual adalah makna sebuah kata atau gabungan kata atau suatu ujaran di dalam konteks pemakaiannya. Konteks di sini bisa berupa konteks kalimat, konteks situasi, atau konteks bidang pemakaian.

\section{Fungsi Emosi}

Bagi manusia, emosi tidak hanya berfungsi untuk survival atau sekedar untuk mempertahankan hidup, seperti pada hewan. Akan tetapi, emosi juga berfungsi sebagai energizer atau pembangkit energi yang memeberikan kegairahan dalam kehidupan manusia. Selain itu, emosi juga merupakan messenger atau pembawa pesan, (Khodijah, 2006).

Khodijah (2006) membagi tiga macam fungsi emosi manusia yaitu:

1) Survival

Survivaladalah sarana untuk mempertahankan hidup. Emosi memberikan kekuatan pada manusia untuk membedakan dan mempertahankan diri terhadap adanya gangguan atau rintangan. Adanya perasaan cinta, sayang, cemburu, marah atau benci, membuat manusia dapat menikmati dalam kebersamaan dengan manusia lain.

2) Energizer

Energizer, yaitu sebagai pembangkit energi. Emosi dapat memberikan manusia semangat dalam bekerja bahkan juga semangat untuk hidup. Contohnya: perasaan cinta dan sayang. Namun, emosi juga dapat memberikan dampak negatif yang membuat manusia merasakan hari-hari yang suram dan nyaris tidak ada semangat untuk hidup. Contohnya; perasaan sedih dan benci.

\section{3) Messenger}

Messenger sebagai pembawa pesan. Emosi memberitahu kita bagaimana keadaan orang-orang yang ada di sekitar kita, terutama orang-orang yang kita cintai dan sayangi. Sehingga kita dapat memahami dan melakukan sesuatu yang tepat dengan kondisi tersebut.

Berkaitan dengan itu, Goleman dan Hammen (dalam Rakhmat, 2001) menyebutkan empat fungsi emosi: (a) Emosi adalah pembangkit energi (energizer). Tanpa emosi, kita tidak sadar atau mati. Hidup berarti merasai, mengalami, bereaksi, dan 

bertindak. Emosi membangkitkan dan memobilisasi energi kita, marah menggerakkan kita untuk menyerang. Takut menggerakkan kita untuk berlari. Dan cinta mendorong kita untuk mendekat dan bermesraan; (b) Emosi adalah pembawa informasi (messenger); (c) Emosi bukan hanya membawa informasi dalam komunikasi interpersonal; (d) Emosi juga merupakan sumber informasi tentang keberhasilan.

Berdasarkan beberapa pendapat tokoh di atas dapat disimpulkan bahwa emosi sangat berfungsi dan memengaruhi kehidupan manusia. Pengaruh emosi lebih terasa apabila manusia dihadapkan pada situasi lingkungan yang ada di sekitarnya dan fungsi dari emosi bisa dijadikan sebagai pengendalian perilaku.

\section{Teori Emosi}

Para ahli mengemukakan beberapa teori dalam upaya menjelaskan timbulnya gejala emosi, beberapa teori tersebut antara lain:

1) Teori emosi dua-faktor Schacter-Singer Teori ini dikenal sebagai teori yang paling klasik yang berorientasi pada rangsangan. Reaksi fisilogik misalnya, hati berdebar, tekanan darah naik, nafas bertambah cepat, adrenalin dialirkan dalam darah. Jika rangsanganya menyenagkan dalam hal ini ketika seseorang merasa gembira seperti diterima di perguruan tinggi idaman, emosi seperti ini disebut emosi senang, sebaliknya jika rangsanganya membahayakan misalnya, melihat ular berbisa yang akan timbul dinamakan taktik.

\section{2) Teori emosi James-lange}

Teori ini menjelaskan bahwa emosi adalah hasil persepsi seseorang terhadap perubahan-perubahan yang terjadi pada tubuh sebagai respon terhadap berbagai rangsangan yang datang dari luar. Jika misalnya seseorang melihat harimau, reaksinya adalah peredaran darah makin cepat memompa udara. Respon tubuh ini kemudian dipersepsikanan timbullah rasa takut. Rasa takut timbul oleh hasil pengalaman dan proses belajar. Orang bersangkutan dari hasil pengalamanya telah mengetahui bahwa harimau adalah makhluk yang berbahaya, karena itu debaran jantung dipersepsikan sebagai rasa takut.

3) Teori emosi emergency Cannon

Teori ini menyatakan emosi timbul bersama-sama dengan reaksi fisologik. Teori Cannon kemudian diperkuat oleh Philp Bard, sehingga kemudian lebih dikenal dengan teori Cannon-Bard atau teori emergency. Teori ini menjelaskan bahwa emosi adalah reaksi yang diberikan oleh organisme dalam situasi darurat atau emergency. Teori ini didasarkan pada pendapat bahwa ada antagonisme pada saraf- saraf simpatis dengan cabangcabang cranial dan sacral pada susunan saraf otonom. Jadi, kalau saraf-saraf simpatif aktif, maka secara otomatif saraf saraf otonom nonaktif, dan begitu sebaliknya.

\section{Fungsi Tuturan}

Searle (dalam Rahardi, 2002) menggolongkan tindak tutur ilokusi itu ke dalam lima macam bentuk tuturan yang masing-masing memiliki fungsi komunikatif. Kelima macam bentuk tuturan yang menunjukkan fungsi komunikasi tersebut sebagai berikut:

(1)Asertif (Assertives), yakni bentuk tuturan yang mengikat penutur pada kebenaran proposisi yang diungkapkan, misalnya menyatakan (stating), yaitu suatu tuturan atau ungkapan untuk memberikan suatu informasi.(suggesting), yaitu tuturan atau ungkapan yang memberikan saran atau pendapat. (boasting), yaitu tuturan atau ungkapan yang digunakan untuk menyatakan rasasombong; mengeluh (complaining), yaitu menyatakan susah karena penderitaan, kesakitan, kekecewaan, dan lain-lain; mengklaim (claiming); membanggakan (to be pround), yaitu tuturan atau ungkapan yang digunakan 

untuk menyatakan rasa bangga; (to raport), yaitu menyatakan informasi kepada seseorang dengan maksud untuk melakukan sesuatu. (2) Direktif (Directives), yakni bentuk tuturan yang dimaksudkan penuturannya untuk membuat pengaruh agar si mitra tutur melakukan tindakan, misalnya memesan (ordering), memerintah (commanding), memohon (requesting), menasehati (advising), dan merekomendasi(recommending).

(3)Ekspresif (Expressives) adalah bentuk tuturan yang berfungsi untuk menyatakan atau menunjukkan sikap psikologis penutur terhadap suatu keadaan, misalnya berterima kasih (thanking), yaitu tindak tutur yang biasanya terjadi karena beberapa faktor diantaranya, yaitu dikarenakan mitra tutur atau lawan tuturnya bersedia melakukan apa yang diminta oleh penutur. (4) Komisif (Commissives) yakni bentuk tuturan yang berfungsi untuk menyatakan janji atau penawaran, misalnya berjanji (promising), yaitu mengucapkan suatu janji, penutur menjanjikan mitra tutur untuk melakukan seperti yang diucapkannya; bersumpah (vowing), yaitu penutur menyatakan (constative) bahwa penutur menyampaikan kebenaran; menawarkan (offering), yaitu mengucapkan tawaran, pentur menawarkan sesuatu kepada mitra tutur. (5) Deklarasi (Declarations) yaitu bentuk tuturan yang menghubungkan isi tuturan dengan kenyataan, misalnya berpasrah (resigning), memecat (dismissing), membaptis (chistening), memberi nama (naming), mengangkat (appointing), mengucilkan (excommicating), dan menghukum (sentencing).

\section{Demonstrasi}

Menurut UU Nomor 9 Tahun 1998

pasal 1 ayat 9 (1), pengertian demonstrasi atau unjuk rasa adalah kegiatan yang dilakukan oleh seorang atau lebih, untuk mengeluarkan pikiran dengan lisan, tulisan dan sebagainya secara demonstratif dimuka umum.
Savero (2008:45) demonstrasi adalah tindakan untuk menyampaikan penolakan, kritik, ketidakberpihakan, mengajari hal-hal yang dianggap sebuah penyimpangan. Unjuk rasa biasanya dilakukan untuk menyatakan pendapat kelompok tersebut atau penentang kebijakan yang dilaksanakan suatu pihak atau dapat pula dilakukan sebagai sebuah upaya penekanan secara politik oleh kepentingan kelompok. Unjuk rasa umumnya dilakukan oleh kelompok mahasiswa yang menentang kebijakan pemerintah, atau para buruh yang tidak puas dengan perlakuan majikannya. Namun unjuk rasa juga dilakukan oleh kelompokkelompok lainnya dengan tujuan lainnya. Unjuk rasa kadang dapat menyebabkan pengrusakan terhadap benda-benda. Hal ini dapat terjadi akibat keinginan menunjukkan pendapat para pengunjuk rasa yang berlebihan yang kadang mengabaikan makna sebenarnya dari demonstrasi.

\section{Wujud Bahasa Demonstrasi}

Mahasiswa beserta gerakannya menggunakan bahasa sebagai salah satu alat penyalur aspirasi. Bahasa yang digunakan sebagai alat komunikasi biasanya berwujud tuturan.

Wujud tuturan adalah jenis atau ragam tuturan yang digunakan seorang penutur dalam menyampaikan pesan kepada mitra tutur. Mengacu pada pandangan Rahardi (2005:87) wujud tuturan dalam bahasa demonstrasi, yakni berwujud formal yang biasa disebut wujud struktural dan wujud pragmatik yang sering disebut wujud nonstruktural. Wujud formal dan wujud pragmatik merupakan dua hal yang perlu dikaitkan dalam memaknai sebuah tuturan. Oleh karena itu, wujud tuturan yang sering dijumpai dalam bahasa demonstrasi yaitu wujud asertif, wujud direktif, wujud ekspresif, dan lain-lain.

Selaras dengan wujud bahasa demonstran, fungsi bahasa berkaitan erat dengan peran alat bahasa sebagai 
penyampain pesan, sehingga akan terdapat fungsi asertif, fungsi direktif, fungsi ekspresif, fungsi deklaratif, dan fungsi komisif.

\section{METODE PENELITIAN \\ Pendekatan dan Jenis Penelitian}

Penelitian ini merupakan jenis penelitian deskriptiif kualitatif dengan menggunakan pendekatan pragmatik. Menurut Sudaryanto (1993), penelitian kualitatif dengan menggunakan metode deskriptif adalah penelitian yang mengindentifikasi, mengklasifikasi, menganalisis data yang diperoleh, dan pendeskripsiannya berupa penggambaran bahasa sebagaimana adanya. Dengan demikian, pendeskripsian data penelitian ini berupa tuturan emosi mahasiswa Kota Baubau dalam ranah demonstrasi dari segi makna dan fungsidengan menggunakan konsep-konsep teori yang dikembangkan oleh para ahli pragmatik. Pendekatan pragmatik digunakan untuk menjelaskan penggunaan tuturan emosi dari aspek konteks atau situasi tutur.

\section{Sumber Data dan Jenis Data}

Sumber data penilitian ini, yaitu empat bentuk demonstrasi mahasiswa Kota Baubau 1) Peringatan hari buru; 2) Perpanjangan izin prodi FKIP Universitas Dayanu Ikhsanuddin; 3) Tuntutan janji kampanye ketua yayasan Universitas Dayanu Iksanuddin; 4) Aksi damai IMM. Jenis data pada penelitian ini terbagi atas dua, yaitu data primer dan data sekunder.

Menurut Hasan (2002), data primer adalah data yang diperoleh atau langsung dikumpulkan di lapangan oleh orang yang melakukan penelitian. Jadi, dalam penelitian ini yang menjadi data primer adalah seluruh tuturan mahasiswa Kota Baubau pada saat berdemonstrasi sedangkan data sekunder adalah data yang dikumpulkan oleh orang yang melakukan penelitian dari sumber yang telah ada.

\section{Populasi dan Sampel}

Sudaryanto (1990), mendefinisikan "populasi sebagai jumlah keseluruhan pemakaian bahasa tertentu yang tidak diketahui batas-batasnya akibat dari banyaknya yang memakai (dari ribuan sampai jutaan), lamanya pemakaian (disepanjang hidup penutur-penuturnya), dan luasnya daerah serta lingkungan pemakaian". Ringkasnya populasi pemakaian bahasa sama dengan jumlah keseluruhan pemakaian bahasa, baik yang akan dipilih maupun tidak dipilih untuk dianalisis. Oleh karena itu, populasi data penelitian ini adalah keseluruhan tuturan emosi mahasiswa Kota Baubau dalam ranah demonstrasi. Penentuan sampel dalam penelitian ini dilakukan dengan cara purposif. Menurut Sugiyono (2010), purposif adalah cara menentukan sampel sesuai dengan yang dibutuhkan peneliti. Adapun sampel yang digunakan dalam penelitian ini sebanyak enam puluh empat kalimat. Enam puluh empat kalimat tersebut dianalisis makna konteks dan fungsi tuturan emosi tersebut.

\section{Teknik Analisis Data}

Menurut Sudaryanto (1993), analisis data adalah upaya peneliti menangani langsung masalah yang terkandung dalam data. Penerapan langkah-langkah dalam teknik analisis data pada penelitian ini sebagai berikut.Persiapan dilakukan dengan menyiapkan seluruh data lapangan, baik berupa rekaman, atau catatan lapangan. Data berupa rekaman suara tersebut ditranskrip atau disalin dalam bentuk tulisan.Penyeleksian datatuturan emosi mahasiswa Kota Baubau yang terdapat dalam rekaman tersebut diseleksi dan ditentukan menurut rumusan masalah yang diteliti yaitu, makna konteks dan fungsituturan emosi tersebut.

Data-data yang diidentifikasi sebelumnya, diklasifikasikan berdasarkan permasalahan yang ada, yakni makna konteks dan fungsi tuturan emosi 
mahasiswa Kota Baubau dalamranah demonstrasi. Dalam penelitian ini klasifikasi dilakukan dengan menggunakan data sesuai dengan tujuan penelitian yang ingin dicapai dan disertakan dengan nomor urut data.Contoh: nomor urut (1)merupakan data satu dan nomor (2) merupakan data dua dan seterusnya.Penganalisisan data yang telah diklasifikasi, kemudian dianalisis dengan mendeksripsikan secara mendetail permasalahan yang terdapat dalam data yang telah dikumpulkan berdasarkan teori yang berkaitan dengan makna konteks dan fungsi tuturan emosi sebagai dasar pedoman dalam menganalisis.Penyimpulan hasil analisispenyimpulan terhadap semua fokus masalah (makna konteks dan fungsi) sebagai karakteristik tuturan emosi mahasiswa Kota Baubau dalam ranah demonstrasi.

\section{PEMBAHASAN}

Penelitian ini menemukan penggunaan makna konteks tuturan emosi mahasiswa Kota Baubau dalam ranah demonstrasi dominan pada makna kontekstual daripada makna leksikal sehingga banyak kata, frasa, kalimat, serta ungkapan yang secara semantik bermakna positif. Namun, secara pragmatik bermakna negatif. Selanjutnya Fungsi tindak tutur Searle terdiri atas lima fungsi sesuai dengan teori tindak tutur yang diterapkan pada penelitian ini, yaitu fungsi asertif, deklaratif, direktif, ekspresif, dan komisif. Namun, dalam penelitian ini hanya ditemukan empat jenis, yaitu asertif, deklaratif, direktif, dan ekspresif.

Fungsi asertif tuturan emosi mahasiswa Kota Baubau dalam ranah demonstrasi diantaranya menyatakan, menyindir, menyarankan, dan mengeluh. Selanjutnya, fungsi deklaratif diantaranya mengejek, pemberian nama, menyalahkan, dan mengancam. Kemudian, fungsi direktif meliputi memerintah, menuntut, dan memohon serta fungsi ekspresif, yaitu menyindir dan memarahi.
Berikut ini contoh analisis makna konteks dan fungsi tuturan emosi dalam ranah demonstrasi.

1. Makna konteks dan fungsiaserif

Asertif adalah bentuk tuturan yang mengikat penutur pada kebenaran proposisi yang diungkapkan

\section{Contoh (1)}

Orator 1: ... Hari buru bukanlah sekadar huforia yang mengandung kesenangan

Orator 2 : ... Semua masyarakat dihipnotis dengan janji di kala itu.

Contoh (1) di atas tampak tuturan emosi, yaitu hari buru bukanlah sekadar huforia yang mengandung kesenangan yang dituturkan oleh orator 1. Piranti linguistik yang menjadi penanda emosinya adalah kata tunggal, yakni huforia. Kata huforia memunyai makna leksikal sebagai tindakan bersenang-senang namun pada konteks ini penutur mengasosiasikan kata tersebut sebagai bentuk kemarahanya. Fungsi kata huforia dalam tuturan tersebut adalah menyatakan. Fungsi asertif menyatakan pada kata huforia dalam konteks ini mengikat otaror 1 pada kebenaran proposisi yang diungkapkannya tentang Hari Buruh bukanlah sekadar memperlihatkan kesenangan atau kebahagiaan namun, hari buruh merupakan hari untuk mengeluarkan semua aspirasi keluhan yang dirasakan oleh para buruh.

Selanjutnya, terdapat pula tuturan orator 2, yaitu semua masyarakat dihipnotis dengan janji dikala itu. Piranti linguistik yang menjadi penanda emosinya adalah kata kompleks dihipnotis yang mengandung fungsimenyatakan. Hipnotis memunyai makna leksikal membuai sedangkan makna konteksnya adalah adnya tindakan pembuaian pemerintah kepada masyarakat. Fungsi kata dihipnotis adalah Fungsi asertif menyatakan pada kata dihipnotis dalam konteks ini, yakni orator 2 mengungkapkan suatu kebenaran yang dianggapnya benar bahwa masyarakat telah dijanjikan 

oleh pemerintah tentang kesejahteraan namun janji tersebut tidak terealisasi.

2. Makna konteks dan fungsi deklaraif Deklaratif adalahbentuk tuturan yang menghubungkan isi tuturan dengan kenyataan.

\section{Contoh (2)}

Orator 1 :... Karena, lagi-lagi sudah terlalu banyak yang menampakkan dirinya untuk menjadi pemimpin di Kota ini layaknya sebuah ajang pencarian bakat dalam dunia selebriti....

Orator 2 : Janji lagi, kalau hanya janji kami juga bisa berjanji Pak ...

Contoh (2) di atas terdapat terlihat tuturan emosi yang digunakan oleh orator 1. Hal ini dapat dilihat melalui tuturan karena, lagi-lagi sudah terlalu banyak yang menampakkan dirinya untuk menjadi pemimpin di Kota ini layaknya sebuah ajang pencarian bakat dalam dunia selebriti merupakan emosi jengkel. Kalimat tersebut menduduki fungsi mengejek. Fungsi deklaratif mengejek dalam konteks ini, yaitu bentuk tuturan yang menghubungkan isi tuturan dengan kenyataan. Dalam hal ini penutur mengungkapkan kenyataan dengan ejekan kepada para pihak politisi yang berharap menjadi walikota di Kota Baubau.

Hal ini terlihat pula pada tuturan orator 2 pada contoh 2, yaitu Melalui contoh (2) di atas tampak dua tuturan emosi, yaitu kalau hanya janji kami juga bisa berjanji Pak.. Tuturan tersebut merupakan bentuk kalimat deklaratif yang mengandung emosi marah yang mempunyai fungsi mengejek. Pada konteks ini orator 2 terikat pada kenyataan dengan mendeklarasikan suatu ejekan kepada para pihak kampus khususnya ketua yayasan Dayanu Ikhsanuddin yang memberikan janji kepada mahasisiwa namun tidak menepatinya.

3. Makna konteks dan fungsi direktif Direktif adalah bentuk tuturan yang dimaksudkan penuturannya untuk membuat pengaruh agar si mitra tutur melakukan tindakan

\section{Contoh (3)}

Orator 1 : ... Harapan kami bahkan masyarakat secara keseluruhan mengharapkan kepada para calon pemimpin yang amanah dan siap bekerja bahkan pemimpin yang selalumendengarkan rintihan rakyatnya dikala mereka susah.Perhatikan nasib mahasiswamu.

Orator2 :Kalaupun belum ada izin akreditasi di kampus ini maka saya ucapkan innalillahi wainailaihi rajiun kepada seluruh civitas akademik di kampus ini.

Contoh (3) di atas tampak tuturan harapan kami bahkan masyarakat secara keseluruhan mengharapkan kepada para calon pemimpin yang amanah dan siap bekerja bahkan pemimpin yang selalu mendengarkan rintihan rakyatnya dikala mereka susah yang dituturkan oleh orator 1 merupakan tuturan emosi. Terdapat kata kompleks mengharapkan yang mengandung jenis emosi kesedihan. Mengharapkan memunyai arti mengimpikan sesuatu hal ini diungkapkan oleh penutur sesuai dengan kenyataan, sehingga makna leksikal sesuai dengan makna konteks. Kata mengharapkan merupakan fungsi memerintah. Pada konteks ini orator 1 menggunakan kata mengharapkan dengan tujuan membuat pengaruh kepada pemerintah untuk melakukan tindakan yang sesuai dengan harapan masyarakatnya.

Selain itu terlihat pula tuturan orator 1 pada contoh (3) di atas yang mengandung emosi rasa takut, yaitu perhatikan nasib mahasiswamu merupakan tuturan emosi. Piranti linguistik yang menjadi penandanya adalah kata kompleks perhatikan yang mengandung fungsi memerintah. Makna leksikal kata perhatikan adalah tindakan sungguh-sungguh untuk mengamati sesuatu. Penggunaan tuturan tersebut sesuai dengan 

konteks sebeanrnya. Pada konteks ini orator 1 menggunakan kata kompleks dengan tujuan membuat pengaruh agar pimpinan kampus, yakni rektor agar dapat melakukan tindakan untuk menyelesaikan masalah perpanjanga izin program studi FKIP.

Adapun tuturan orator 2 pada contoh

(3) di atas, yaitu "kalaupun belum ada izin akreditasi di kampus ini, maka kita ucapkan innalillahi wainailihi rajiun kepada seluruh civitas akademik di kampus ini" merupakan tuturan emosi. Piranti linguistik yang menjadi penandanya adalah kalimat imperatif "kita ucapkan innalillahi wainailaihi rajiun". Kalimat imperatif tersebut merupakan jenis emosi negatif jengkel, yang memunyai fungsi menyindir pihak kampus yang dianggap oleh orator 2 bahwa mereka tidak bisa menyelesaikan izin operasional kampus Universitas Dayanu Ikhsanudin.

4. Makna konteks dan fungsi ekspresif Ekspresif adalah bentuk tuturan yang berfungsi untuk menyatakan atau menunjukkan sikap psikologis penutur terhadap suatu keadaan.

\section{Contoh (4)}

Orator 3 :... Wahai generasi mudah apakak engkau hanya menjadi saksi sejarah? ...

Orator 4 : Janji lagi, kalau hanya janji kami juga bisa berjanji Pak. ... kami bosan sekali dengan hanya menerima solusi yaitu janji-janji.

Pada contoh (4) di atas tergambar tuturan orator 3 yang mengandung emosi kesedihan, yaitu wahai generasi mudah apakah engkau hanya menjadi saksi sejarah?. Piranti linguistik yang menjadi penandanya adala frasa nomina saksi sejarah yang memunyai fungsi menyindir. Makna leksikal saksi sejarah berarti orang yang mengetahui suatu peristiwa. Namun pada konteks ini penutur menggunakan frasa tersebut sebagai ungkapan tidak suka terhadap sikap generasi muda yang tidak peka terhadap persoalan yang terjadi di Kota Baubau.
Terlihat pula pada tuturan orator 4 yaitu kami bosan sekali dengan hanya menerima solusi, yaitu janji-janji merupakan tuturan emosi yang mempunyai fungsi memarahi. Piranti linguistik yang menjadi penandan emosi marah pada tuturan tersebut adalah frasa ajektiva bosan sekali. Frasa bosan memunyai makna leksikal, yaitu adanya rasa jenuh terhadap suatu hal sedangkan makna konteksnya sesuai dengan makna leksikalnya. Fungsi frasa bosan sekali dalam tuturan tersebut adalah memarahi. Fungsi tersebut sebagai tuturan mengikat terhadap oknum yang dituju dalam hal ini pihak kampus yang memeberikan solusi tidak tepat terhadap penyelesaian perpanjangan izin program studi FKIP.

\section{PENUTUP}

\section{Simpulan dan Saran}

Berdasarkan hasil kajian bab sebelumnya (hasil dan pembahasan), penulis dapat menarik beberapa kesimpulan yang selaras dengan tujuan penelitian, yaitu Makna tuturan emosi tersebut lebih dominan pada makna kontekstual dibanding dengan makna leksikal sehingga banyak kata, frasa, kalimat, dan ungkapan yang secara semantik bermakna positif namun secara pragmatik bermakna negatif. Fungsi tuturan emosi mahasiswa Kota Baubau yaitu, asertif, ekspresif, direktif, dan deklaratif.

Bagi pemerintah agar lebih memahami bahwa demonstrasi bukanlah sebuah gerakan yang kurang baik tetapi demonstrasi dapat menimbulkan efek positif bagi kemajuan suatu daerah. Bagi mahasiswa dalam berdemostrasi harus dapat mengontrol tuturan dan sikapnya karena seringkali aksi demostrasi diwarnai denga fitnah bahkan tindakan anarkis yang menyebabkan kerugian bagi mahasiswa yang berdemostrasi. Dapat memberikan pemahaman terhadap masyarakat bahwa demonstrasi dapat menimbulkan efek yang baik selama demonstrasi berada pada koridor dan aturan yang tepat serta dapat melatih 

konsep retorika mahasiswa. Penelitian ini menjawab persepsi pemerintah dan masyarakat bahwa tidak selamanya demonstrasi menimbulkan tindakan yang anarkis melainkan demonstrasi dapat memberikan solusi demi tertatanya birokrasi pemerintah yang baik.

\section{DAFTAR PUSTAKA}

Abdulsyani. 1994. Sosiologi: Skematika, Teori dan Terapan. Jakarta: Bumi Aksara.

Cahyono, Bambang Yudi. 1995. KristalKristal Ilmu Bahasa. Surabaya: Airlangga.

Chaer A. (2012). Linguistik Umum. Jakarta: Rineka Cipta.

Dirgagunarsa, Singgih. 1978. Pengantar Psikologi. Jakarta: Mutiara.

Goleman, Daniel. 2001. Kecerdasan Emosi untuk Mencapai Puncak

Prestasi. Jakarta: PT Gramedia Pustaka Utama.

Gusnawaty. 2011. "Perilaku Kesantunan dalam Bahasa Bugis Analisis Sosiopragmatik".

Disertasi.

Makassar:

Pascasarjana

Universitas Hasanuddin.

Hasan. (2002). Pokok-pokok Materi Metodologi Penelitian dan Aplikasinya. Bogor: Ghalia.

Iye, Risman. "Tuturan emosi mahasiswa kota baubau dalam ranah demonstrasi [emotional speech of the students in baubau city in the demonstration]." TOTOBUANG, 6 (1), 125138 (2018).

Iye, Risman, Jl Prof Dr HAR Basalamah No, and Namlea-Kab Buru. "TUTURAN DALAM PROSESI LAMARAN PERNIKAHAN DI TOMIA KABUPATEN WAKATOBI."

Khodijah. (2006). Psikologi Pelajar. IAIN. Raden Fatah Press.
Leech, Geoffrey. 1993. Prinsip-Prinsip Pragmatik. Penerjemah: M.D.D Oka. Jakarta: Penerbit Universitas Indonesia.

Nababan, P.W.J. 1987. Ilmu Pragmatik, Teori dan Penerapannya. Jakarta: Gramedia.

Nurhayati. 2006. "Bahasa Emosi Wanita Karier di Kota Makassar Kajian Psikososiolinguistik”. Disertasi. Makassar:PascasarjanaUniversitas Hasanuddin.

Rahardi. (2002). Sosiolinguistik, Kode, dan Alih Kode. Yogyakarta: Pustaka Pelajar.

Rakhmat, Djalaluddin. 2001. Metode Penelitian. Bandung. Angkasa.

Rusminto .2010. Pragmatik Teori dan Analisis. Surakarta: Pustaka.

Rustono. 1999. Pokok-Pokok Pragmatik. Semarang: CV. Ikip Semarang Press.

Savero, Bobby. 2008. "Demonstrasi Perjuangan Kontekstual": www.

Wikimu.com (selasa 26 mei 2008).

Sudaryanto. (1993). Metode dan Aneka Teknik Analisis Bahasa. Yogyakarta: Duta Wacana University Press.

Sudaryanto. (1990). Aneka Konsep Kedatan Lingual dalam Linguistik. Yogyakarta: Wacana University Press.

Sugiyono. (2010). Metode Penelitian Kuantitatif Kualitatif dan RND. Bandung: Alfabeta.

Ullman, Steohen. 2007. Pengantar Linguistik. (Pengadaptasi: Sumarsono dari Judul Asli; Semantics, An Introduction To The Science Meaning). Yogyakarta: Pustaka Pelajar.

Walgito, Bimo. 2003. Pengantar Psikologi Umum. Yogyakarta: Andi Offset.

Sam, B., Iye, R., Ohoibor, M., Umanailo, M. C. B., Rusdi, M., Rahman, A. B. D., \& Hajar, I. (2019). Female 
Feminism in the Customary Island of Buru. Int. J. Sci. Technol. Res, 8(8), 1877-1880.

Susiati, S. (2018). Homonim bahasa kepulauan tukang besi dialek kaledupa di kabupaten wakatobi [the homonymon of tukang besi island languange in kaledupa dialect at wakatobi regency]. Totobuang, 6 (1), 109, 123.

Iye, R., \& Susiati, S. (2018). NILAI EDUKATIF DALAM NOVEL SEBAIT CINTA DI BAWAH LANGIT KAIRO KARYA MAHMUD JAUHARI ALI (Educative Values in Sebait Cinta di Bawah Langit Kairo by Mahmud Jauhari Ali). Sirok Bastra, 6(2), 185-191.

Susiati, S., Iye, R., \& Suherman, L. O. A. (2019). Hot Potatoes Multimedia Applications in Evaluation of Indonesian Learning In SMP Students in Buru District. ELS Journal on Interdisciplinary Studies in Humanities, 2(4), 556-570.

Susiati, S., \& Iye, R. (2018). Kajian Geografi Bahasa dan Dialek di Sulawesi Tenggara: Analisis Dialektometri. Gramatika: Jurnal Ilmiah Kebahasaan dan Kesastraan, 6(2), 137-151.

Iye, R., Susiati, S., \& Karim, K. (2020). Citra Perempuan dalam Iklan Sabun Shinzui. Sang Pencerah: Jurnal Ilmiah Universitas Muhammadiyah Buton, 6(1), 17.

Lafamane, F. (2020). Perkembangan Teori Sastra (suatu Pengantar).

Susiati, S. (2020). GAYA BAHASA
SECARA UMUM DAN GAYA BAHASA PEMBUNGKUS PIKIRAN.

Iye, R. (2018). Tuturan emosi mahasiswa kota baubau dalam ranah demonstrasi.

Iye, R., Tenriawali, A. Y., Susiati, A., \& Buton, D. (2020). Makna dan Fungsi Emosi Mahasiswa Kota Baubau dalam Ranah Demonstrasi: The Meaning And Emotional Function Of Students Of Baubau City In The Demonstration Plan. Uniqbu Journal of Social Sciences, 1(1), 25-37.

Lafamane, F. (2020). Perkembangan Teori Sastra (suatu Pengantar).

Lafamane, F. (2020). Perkembangan Teori Sastra (suatu Pengantar).

Buru, K. M. S. PENGARUH MOTIVASI BELAJAR DI SMA NEGERI 2 BURU.

Yusnan, M., Kamasiah, R. I., Karim, H., \& Bugis, R. (2020). Alih Kode dan Campur Kode pada Novel Badai Matahari Andalusia Karya Hary El-parsia: Transfer Code And Mix Code In Novels Badai Matahari Andalusia Karya Hary El-parsia. Uniqbu Journal of Social Sciences, 1(1), 1-12.

YANTI, K. NILAI-NILAI MORAL DALAM TOKOH UTAMA PADA NOVEL SATIN MERAH.

Susiati, S. (2020). Konsep Pertentangan Dalam Film" Aisyah Biarkan Kami Bersaudara" Karya Herwin Novianto.

Susiati, S. (2020). Gaya Bahasa Secara 
Umum Dan Gaya Bahasa Pembungkus Pikiran: Stilistika.

Iye, R., Tenriawali, A. Y., Susiati, A., \& Buton, D. (2020). Makna dan Fungsi Emosi Mahasiswa Kota Baubau dalam Ranah Demonstrasi: The Meaning And Emotional Function Of Students Of Baubau City In The Demonstration Plan. Uniqbu Journal of Social Sciences, 1(1), 25-37.

Iye, R. WRITING SKILLS IN SMP USWATUN HASANAH. BURU DISTRICT.

iye, r. (2020, March 10). DEIKSIS MASYARAKAT BONEGUNU KABUPATEN BUTON UTARA. https://doi.org/10.31228/osf.io/se qan. 10.31228/osf.io/seqan

Iye, R. (2018). Tuturan dalam Prosesi Lamaran Pernikahan di Tomia Kabupaten Wakatobi. Jurnal Totobuang, 6(2).

Susiati, S. (2020). PENTINGNYA MELESTARIKAN BAHASA DAERAH.

Umanailo, M. C. B. Cia-Cia Vocational Inventoryization In Buru District.

BURU, U. I. MODEL KOOPERATIF LEARNING TIPE STAD DALAM MENINGKATKAN KEMAMPUAN MENGAPRESIASI CERITA FIKSI DI SD NEGERI 1 NAMLEA.

Iye, R. H. NILAI-NILAI MORAL DALAM TOKOH UTAMA PADA NOVEL SATIN
MERAH

KARYA

BRAHMANTO ANINDITO

DAN RIE YANTI. TELAGA

BAHASA,(7), 2, 195-206.

Lafamane, F. (2020). Perkembangan Teori Sastra (suatu Pengantar).

Iye, R. J1 Prof Dr HAR Basalamah No, and Namlea-Kab Buru.". TUTURAN DALAM PROSESI LAMARAN PERNIKAHAN DI TOMIA KABUPATEN WAKATOBI." Kontemporer. Bandung: PT Remaja.

Harziko, H., Said, I. M., \& Darwis, K. (2018). FOLLOW THE EVENTS IN THE INDONESIAN LANGUAGE EXPRESSIVE SAID TRANSACTION IN THE TRADITIONAL MARKET TOWN OF BAUBAU. JURNAL ILMU BUDAYA, 6(1).

Sam, B., Iye, R., Ohoibor, M., Umanailo, M. C. B., Rusdi, M., Rahman, A. B. D., \& Hajar, I. (2019). Female Feminism in the Customary Island of Buru. Int. J. Sci. Technol. Res, 8(8), 1877-1880.

Susiati, S. (2018). Homonim bahasa kepulauan tukang besi dialek kaledupa di kabupaten wakatobi [the homonymon of tukang besi island languange in kaledupa dialect at wakatobi regency]. Totobuang, 6 (1), 109, 123.

Iye, R., \& Susiati, S. (2018). NILAI EDUKATIF DALAM NOVEL SEBAIT CINTA DI BAWAH LANGIT KAIRO KARYA MAHMUD JAUHARI ALI (Educative Values in Sebait Cinta di Bawah Langit Kairo by Mahmud Jauhari Ali). Sirok Bastra, 6(2), 185-191. 
Susiati, S., Iye, R., \& Suherman, L. O. A. (2019). Hot Potatoes Multimedia Applications in Evaluation of Indonesian Learning In SMP Students in Buru District. ELS Journal on Interdisciplinary Studies in Humanities, 2(4), 556-570.

Susiati, S., \& Iye, R. (2018). Kajian Geografi Bahasa dan Dialek di Sulawesi Tenggara: Analisis Dialektometri. Gramatika: Jurnal Ilmiah Kebahasaan dan Kesastraan, 6(2), 137-151.

Iye, R., Susiati, S., \& Karim, K. (2020). Citra Perempuan dalam Iklan Sabun Shinzui. Sang Pencerah: Jurnal Ilmiah Universitas Muhammadiyah Buton, 6(1), 17.

Lafamane, F. (2020). Perkembangan Teori Sastra (suatu Pengantar).

Susiati, S. (2020). GAYA BAHASA SECARA UMUM DAN GAYA BAHASA PEMBUNGKUS PIKIRAN.

Iye, R. (2018). Tuturan emosi mahasiswa kota baubau dalam ranah demonstrasi.

Iye, R., Tenriawali, A. Y., Susiati, A., \& Buton, D. (2020). Makna dan Fungsi Emosi Mahasiswa Kota Baubau dalam Ranah Demonstrasi: The Meaning And Emotional Function Of Students Of Baubau City In The Demonstration Plan. Uniqbu Journal of Social Sciences, 1(1), 25-37.

Lafamane, F. (2020). Perkembangan Teori Sastra (suatu Pengantar).
Lafamane, F. (2020). Perkembangan Teori Sastra (suatu Pengantar).

Buru, K. M. S. PENGARUH MOTIVASI BELAJAR DI SMA NEGERI 2 BURU.

Yusnan, M., Kamasiah, R. I., Karim, H., \& Bugis, R. (2020). Alih Kode dan Campur Kode pada Novel Badai Matahari Andalusia Karya Hary El-parsia: Transfer Code And Mix Code In Novels Badai Matahari Andalusia Karya Hary El-parsia. Uniqbu Journal of Social Sciences, 1(1), 1-12.

YANTI, K. NILAI-NILAI MORAL DALAM TOKOH UTAMA PADA NOVEL SATIN MERAH.

Susiati, S. (2020). Konsep Pertentangan Dalam Film" Aisyah Biarkan Kami Bersaudara" Karya Herwin Novianto.

Susiati, S. (2020). Gaya Bahasa Secara Umum Dan Gaya Bahasa Pembungkus Pikiran: Stilistika.

Iye, R., Tenriawali, A. Y., Susiati, A., \& Buton, D. (2020). Makna dan Fungsi Emosi Mahasiswa Kota Baubau dalam Ranah Demonstrasi: The Meaning And Emotional Function Of Students Of Baubau City In The Demonstration Plan. Uniqbu Journal of Social Sciences, 1(1), 25-37.

Iye, R. WRITING SKILLS IN SMP USWATUN HASANAH. BURU DISTRICT.

iye, r. (2020, March 10). DEIKSIS MASYARAKAT BONEGUNU KABUPATEN BUTON UTARA. https://doi.org/10.31228/osf.io/seq 
an. 10.31228/osf.io/seqan

Iye, R. (2018). Tuturan dalam Prosesi Lamaran Pernikahan di Tomia Kabupaten Wakatobi. Jurnal Totobuang, 6(2).

Susiati, S. (2020). PENTINGNYA MELESTARIKAN BAHASA DAERAH.

Umanailo, M. C. B. Cia-Cia Vocational Inventoryization In Buru District.

BURU, U. I. MODEL KOOPERATIF LEARNING TIPE STAD DALAM MENINGKATKAN KEMAMPUAN

MENGAPRESIASI CERITA FIKSI DI SD NEGERI 1 NAMLEA.

Iye, R. H. NILAI-NILAI MORAL DALAM TOKOH UTAMA PADA NOVEL SATIN MERAH KARYA BRAHMANTO ANINDITO DAN RIE YANTI. TELAGA BAHASA,(7), 2, 195-206.

Lafamane, F. (2020). Perkembangan Teori Sastra (suatu Pengantar).

Iye, R. J1 Prof Dr HAR Basalamah No, and Namlea-Kab Buru.". TUTURAN DALAM PROSESI LAMARAN PERNIKAHAN DI TOMIA KABUPATEN WAKATOBI." Kontemporer. Bandung: PT Remaja.

Harziko, H., Said, I. M., \& Darwis, K. \begin{tabular}{lrr} 
(2018). FOLLOW & THE \\
EVENTS & IN & THE \\
INDONESIAN & LANGUAGE \\
EXPRESSIVE & & SAID \\
TRANSACTION & IN & THE \\
TRADITIONAL & \multicolumn{2}{r}{ MARKET }
\end{tabular}
TOWN OF BAUBAU. JURNAL ILMU BUDAYA, 6(1). 